Katarzyna Kruk-Junger (D)

Uniwersytet Pedagogiczny im. KEN w Krakowie

katarzyna.kruk-junger@up.krakow.pl

\title{
Kompetencje miękkie tłumacza w ujęciu interdyscyplinarnym
}

\section{Kompetencje miękkie w teorii przekładu}

Wydaje się, że - zarówno w literaturze przedmiotu, jak i obiegowej opinii - istnieje wiele nieporozumień dotyczących zjawiska kompetencji tłumacza. Jest nim np. pogląd, że każdy, kto włada dwoma językami, może być tłumaczem. I choć ta supozycja została już podważona, kwestia umiejętności niezbędnych do wykonywania tego zawodu nadal wywołuje wiele dyskusji. Listy kompetencji stają się wprawdzie coraz bardziej kompletne i ugruntowane w badaniach, jednak ta ich część, która należy do tzw. kompetencji miękkich, nadal traktowana jest bez należytej uwagi. Temat ten stał się ostatnio dość ,modny” w naukach społecznych, zwłaszcza w badaniach związanych z Business Studies, a do pewnego stopnia również $\mathrm{w}$ dydaktyce na poziomie uniwersyteckim, która aspiruje dziś do zapewnienia absolwentom umiejętności niezbędnych do dobrego funkcjonowania na rynku pracy. A jednak nie doczekał się on głębszego opracowania teoretycznego, i to nie tylko w badaniach nad przekładem, ale także, co ciekawe, w zakresie psychologii społecznej i innych podobnych dyscyplinach. Jednak znaczenie tych umiejętności, 
postulowanych przez teoretyków i praktyków biznesu, trudno przecenić. Specjaliści od zarządzania zasobami ludzkimi mawiają podobno, że: „Pracę otrzymuje się w 70\% dzięki wiedzy fachowej i w 30\% dzięki zdolnościom społecznym. Traci się ją zaś w 70\% z braku zdolności społecznych i w 30\% z braku kwalifikacji merytorycznych" [Płuska 2017]. I chociaż to humorystyczne oświadczenie prawdopodobnie nigdy nie zostało potwierdzone naukowo, to jednak należy się zastanowić, czy to samo dotyczy zawodu tłumacza. Jeśli tak, to kompetencje miękkie powinny zostać potraktowane $z$ większym niż do tej pory szacunkiem, i to zarówno przez badaczy, jak i praktyków przekładu.

We wczesnych teoriach językoznawczych i przekładoznawczych kompetencje tłumaczeniowe były postrzegane jako bardzo specyficzna wiedza, często ograniczona do języka i słownictwa związanego z dziedziną, w której pracował tłumacz. Ten pogląd, zapoczątkowany przez badaczy-językoznawców, podzielali Jean-Paul Vinay i Jean Darbelnet [1958] czy Roman Jakobson [1959]. Przez wiele lat to podejście było dominujące, jednak rozwój studiów translatorskich jako dziedziny odrębnej od językoznawstwa pomógł je przezwyciężyć. Nowa dyscyplina szybko zaczęła rozwijać własne narzędzia naukowe, co pozwoliło lepiej zrozumieć proces thumaczenia i postawić wiele interesujących pytań dotyczących kompetencji tłumacza. Niestety nie znaleziono prostych odpowiedzi. Kolejni badacze proponowali własne listy umiejętności, które obejmowały m.in. zdolności w zakresie transferu i pozajęzykowe, ale nadal brakowało dokładniejszych badań dotyczących ich znaczenia i praktycznych zastosowań [Albin 2014].

Jednym z pierwszych badaczy, którzy dostrzegli potrzebę uwzględnienia kompetencji miękkich w przekładzie, był Gideon Toury, który przyznał wprost, że umiejętne tłumaczenie tekstu wymaga czegoś więcej niż kompetencji językowych:

„tłumaczenie” oznacza przede wszystkim umiejętność odgrywania roli społecznej, tj. wypełniania funkcji przydzielonej przez społeczeństwo tej działalności, osobom, które ją wypełniają, i/lub produktom tej działalności, w sposób, który uważa się za odpowiedni. Przyjęcie zestawu norm, które służyć mają do określenia adekwatności tego rodzaju zachowań oraz manewrowanie między wszystkimi czynnikami, które mogą je ograniczać, jest zatem podstawowym warunkiem zostania thumaczem w środowisku kulturowym [1995: 53, thum. K.K.J.]. 
Autor sugeruje, że tłumacz powinien przejść „,socjalizację”, która pozwoli mu zdobyć kompetencje niezbędne do odegrania określonej roli społecznej. Osiąga się ją dzięki praktyce i doświadczeniu, dlatego zdaje się ona nie mieć żadnego wpływu na przygotowanie przyszłego tłumacza w procesie edukacji do codziennej praktyki zawodowej. Choć trudno nie zgodzić się z samym założeniem procesu socjalizacji, to te konkluzje wydają się bardzo pesymistycznym podejściem do dydaktyki przekładu.

Nieco inne podejście proponują badacze, którzy analizują thumaczenie z perspektywy transferu kulturowego, a nie wyłącznie językowego. Stanowisko Davida Katana [1999] należy do najciekawszych, gdyż postuluje on poszerzenie roli thumacza do funkcji mediatora kulturowego, odpowiedzialnego za komunikację w szerokim tego słowa znaczeniu i upoważnionego do interweniowania $\mathrm{w}$ interakcję w celu umożliwienia pełnego zrozumienia kontekstu kulturowego. Przejmuje on cztery grupy kompetencji zaproponowane przez Ronalda Tafta dla mediatorów kulturowych: wiedzę o społeczeństwie (wiedza o kulturze), umiejętności komunikacyjne (zarówno werbalne, jak i pozawerbalne), umiejętności techniczne konieczne do wykonania przekładu, a także umiejętności społeczne, pozwalające na funkcjonowanie w społeczeństwie [Taft 1981, za: Katan 1999: 12]. Ten ostatni zestaw kompetencji, jak skutecznie argumentuje Katan, jest równie ważny w działalności tłumaczeniowej, ponieważ mediacja kulturowa jest w zasadzie główną rolą tłumacza.

Ciekawych danych do analizy działalności tłumaczeniowej z perspektywy kompetencji miękkich dostarczają badacze przekładu ustnego. I choć niewątpliwie ten rodzaj thumaczenia wymaga od pośrednika językowego nieco innego zestawu umiejętności niż przekład pisemny, warto przyjrzeć się, na ile osiągnięcia badaczy w tej dziedzinie pozwalają na szersze wnioski, istotne dla całej dziedziny przekładoznawstwa. I tak, Daniel Gile w swojej książce Basic Concepts and Models for Interpreter and Translator Training zaproponował szereg kompetencji, których przydatność nie ogranicza się do tłumaczenia ustnego. Są to m.in.: znajomość obu języków, odpowiednia wiedza o świecie, znajomość dyscypliny, w której pracuje tłumacz (choć w przypadku tłumaczeń ustnych konieczna jest dodatkowa znajomość strategii, które mogą zrekompensować braki w tym zakresie), umiejętności techniczne, sprawność intelektualna itp. Gile kładzie również duży nacisk na umiejętność zachowania się w sposób profesjonalny, ponieważ pomaga to w podnoszeniu „statusu społecznego" całego zawodu. Autor uważa, dość optymistycznie, że większość tych 
kompetencji może zostać wykształcona w toku edukacji, a więc szkolenie tłumaczy powinno zostać zoptymalizowane w tym zakresie [Gile 1995]. Podobny pogląd, ze szczególnym naciskiem na umiejętność etycznego radzenia sobie z problemami w komunikacji, można znaleźć w badaniach dotyczących tłumaczeń dialogowych [por. Gentile, Ozolins et al. 1996]. Również Franz Pöchhacker [2004], zajmujący się przekładem środowiskowym, podkreśla znaczenie pewnych osobistych kompetencji w pracy tłumacza. Powołując się na badania przeprowadzone już w 1931 roku przez hiszpańskiego psychologa na grupie 20 thumaczy konferencyjnych, pracujących w wybranych organizacjach międzynarodowych, rozróżnia takie umiejętności jak „zdolności poznawcze (np. inteligencja, intuicja, pamięć) oraz cechy moralne i afektywne (np. takt, dyskrecja, czujność, opanowanie)" [Sanz 1931, za: Pöchhacker 2004: 166]. Autor poszerza tę listę o propozycję Hoofa, który dodaje ,cechy fizyczne, takie jak wytrzymałość i mocne nerwy, intelektualne, w szczególności znajomość języka i szeroką wiedzę ogólną, oraz umysłowe, takie jak pamięć, rozsądek, koncentrację i podzielność uwagi" do listy wstępnych umiejętności niezbędnych w thumaczeniu dialogowym [Hoof 1962, za: Pöchhacker 2004: 166]. Przykłady te zdają się sugerować, że konieczność uwzględnienia kompetencji miękkich na liście kwalifikacji tłumacza jest szczególnie widoczna w kontekście przekładu ustnego, można jednak śmiało założyć, że te same cechy mogą być pomocne, a nawet pożądane, w kontekście thumaczenia pisemnego.

Podobne wnioski płyną z badań w obrębie praktyki i dydaktyki przekładu, w których odnotowuje się coraz większe zainteresowanie umiejętnościami pozajęzykowymi w procesie kształcenia tłumaczy.

\section{Kompetencje miękkie w dydaktyce i praktyce przekładu}

Jednym z najbardziej ambitnych badań dotyczących kompetencji tłumacza przeprowadzonych do tej pory jest projekt PACTE, prowadzony na Universitat Autònoma w Barcelonie. Imponujące i dogłębne badania kompetencji przeprowadzone przez grupę badaczy pomogło w stworzeniu listy umiejętności niezbędnych tłumaczowi. Są to:

- subkompetencja dwujęzyczna - czynna znajomość dwóch języków;

- subkompetencja pozajęzykowa - wiedza specyficzna dla danej dziedziny, kulturowa, encyklopedyczna oraz ogólna o świecie; 
- wiedza o tłumaczeniu - związana $\mathrm{z}$ profesjonalną praktyką thumaczeniową;

- subkompetencja instrumentalna - wiedza na temat zasobów, takich jak słowniki itp.;

- subkompetencja strategiczna - umiejętność rozwiązywania problemów tłumaczeniowych z wykorzystaniem wszystkich pozostałych subkompetencji;

- komponenty psychofizjologiczne - cechy osobiste tłumacza, które mogą wpływać na proces tłumaczenia, należące do cech kognitywnych (pamięć, percepcja, uważność, emocje itd.), związane z nastawieniem (ciekawość intelektualna, wytrwałość, dyscyplina, krytyczne myślenie itd.) lub ogólnymi zdolnościami (kreatywność, logiczne rozumowanie, analiza, synteza itd.) [PACTE 2009, tłum. K.K.J.].

Wyniki tych badań mają ogromne znaczenie dla oceny znaczenia kompetencji miękkich w tłumaczeniu i staną się, miejmy nadzieję, podstawą do dalszych prac, mających wskazać, jakie dokładnie „komponenty psychofizjologiczne" są konieczne do wykonywania tego zawodu oraz w jaki sposób rozwijać je w toku edukacji. Próbę stworzenia takiej listy umiejętności na podstawie tych wyników podjęła Dorothy Kelly [2014]. Zaproponowała ona obszerną listę kompetencji tłumacza, które powinny zostać uwzględnione $\mathrm{w}$ toku kształcenia tłumaczy, które podzieliła na kompetencje: komunikacyjną i tekstową, kulturową i międzykulturową, przedmiotową, zawodową i instrumentalną, w zakresie nastawienia i psychofizjologii, interpersonalną oraz strategiczną [Kelly 2014, tłum. K.K.J.]. Trzy ostatnie grupy zdają się określać kompetencje miękkie, chociaż ta terminologia nie jest tu stosowana - jest to problem, który omówimy dokładniej poniżej. Jest to jednak najdalej idący głos w dyskusji na temat konieczności włączenia umiejętności społecznych do profilu tłumacza, a w konsekwencji do programu kształcenia.

Ciekawe badanie dotyczące tej kwestii zostało przeprowadzone i opublikowane w 2014 roku przez Joannę Albin. W swoim opracowaniu, nastawionym na codzienną praktykę zawodową, autorka demonstruje braki w wykształceniu akademickim tłumaczy oraz konieczność samodzielnego ich zdobywania w toku pracy. W ocenie badanych tłumaczy wysoką pozycję zajęły takie kompetencje jak zdolności badawcze, biegłość w zakresie języków, organizacja pracy, umiejętność obsługi komputera i ogólna wiedza. Wszystkie one zdają się potwierdzać zaprezentowane wcześniej zestawienia. Interesujące jednak jest to, że wyniki te wyraźnie 
ukazują konieczność uwzględnienia kompetencji nieujętych w większości proponowanych list, które Albin określa jako ,umiejętności zarządzania" zawierające $\mathrm{w}$ sobie takie elementy jak autopromocja, negocjacje, praca zespołowa [Albin 2014: 79-80].

Niewątpliwą oznaką pozytywnych zmian w zakresie włączenia kompetencji miękkich do profilu thumacza jest publikacja udoskonalonej i zmienionej listy umiejętności w modelu EMT (European Master's in Translation). Zastąił on „,koło kompetencji” wprowadzone w 2009 roku, a które w ostatnim czasie „stało się jednym z wiodących standardów referencyjnych w zakresie szkolenia thumaczy i kompetencji tłumaczeniowych w całej Unii Europejskiej i poza nią, zarówno w kręgach akademickich, jak i w branży językowej" [EMT Competence Framework 2017]. Nowe ramy kształcenia organizują pożądane kompetencje w pięciu grupach: język i kultura, thumaczenie, technologia, osobiste i interpersonalne oraz świadczenie usług [ibidem]. Takie podejście $\mathrm{w}$ dydaktyce jest niewątpliwie krokiem we właściwym kierunku, jeśli chodzi o uwzględnienie i docenienie miejsca kompetencji miękkich w profilu thumacza. Ramy w sekcji osobistej i interpersonalnej wyraźnie obejmują takie umiejętności jak: zarządzanie czasem i stresem, praca zespołowa, stosowanie ergonomii organizacyjnej i fizycznej w miejscu pracy, umiejętność samooceny i stosowania strategii rozwoju. Ponadto niektóre umiejętności wymienione w obszarze świadczenia usług, które odnoszą się do sfery komunikacji $\mathrm{z}$ klientem, czyli umiejętności interpersonalne $\mathrm{w}$ zakresie kontaktowania się z klientami, wyjaśniania oczekiwań, negocjacji, organizowania pracy, wdrażania i zarządzania standardami zawodowymi, a także przestrzegania profesjonalnych kodeksów etycznych [ibidem], należy również uznać za kompetencje społeczne.

Tutaj jednak natrafiamy na problem, który zdaje się charakteryzować wszystkie listy kompetencyjne tworzone przez i dla tłumaczy: brakuje im ogólnej definicji, czym są kompetencje i jakie mają cechy. Większość prezentowanych propozycji to dość subiektywny zestaw obserwacji i pomysłów. Nawet kiedy opierają się one na bardziej obiektywnych danych, są albo bardzo ogólne, albo brakuje im systematycznego ujęcia. I chociaż $\mathrm{w}$ niektórych $\mathrm{z}$ tych propozycji wymienia się kompetencje miękkie, nie stosuje się tej nazwy, co w konsekwencji utrudnia porównywanie ich $\mathrm{z}$ opracowaniami przygotowanymi w ramach innych dziedzin nauk, zwłaszcza społecznych. To niestety świadczy o tym, że teoretycy przekładu niechętnie czerpią z innych dyscyplin (ze wspomnianymi wyżej, 
godnymi uwagi, ale rzadkimi wyjątkami). Nawet osiągnięcia w powiązanych obszarach badań są często ignorowane. Jak inaczej wytłumaczyć fakt, że, pomijając propozycję PACTE, żadna inna z wyżej wymienionych list nie uwzględnia umiejętności społecznej, którą od dawna podkreślają literaturoznawcy zajmujący się krytyką przekładu, czyli graniczącej z artyzmem kreatywności? Takie stanowisko zajmują np. Etkind i Faigel [1967], a w Polsce Zygmunt Grosbart [2006] czy Anna Bednarczyk [2005, 2012]. O procesie - nomen omen - „tworzenia” przekładu z punktu widzenia szkoły hermeneutycznej pisze także Jerzy Brzozowski w artykule „Czy istnieje w Polsce szkoła hermeneutyczna w przekładzie?” [2004]. Z kolei Małgorzata Brożyna-Reczko w swojej publikacji poświęconej „kompetencji twórczej tłumacza” nawiązuje do osiągnięć glottodydaktyki, która opisuje dość dokładnie tę cechę. Zestawiając ją z osiągnięciami przekładoznawców, stwierdza, że w wielu istniejących modelach i definicjach ta umiejętność jest często jedynie implikowana w ramach innych subkompetencji [2017: 18-19]. I choć ta kompetencja rzeczywiście pojawia się na marginesie rozważań na temat kształcenia tłumaczy, to jednak nie została nigdzie opisana i zdefiniowana w sposób jednoznaczny $i$, podobnie zresztą jak pozostałe kompetencje miękkie, najczęściej nie pojawia się w głównym nurcie rozważań nad pojęciem umiejętności i kwalifikacji tłumacza oraz sposobem ich osiągnięcia w toku dydaktyki [por. np. Piotrowska 2007, 2016].

\section{Kompetencje miękkie z perspektywy innych dziedzin naukowych}

Nie ujmując niczego wcześniej cytowanym rozważaniom w zakresie nauk o tłumaczeniu, należy zaznaczyć, że kwestia kompetencji społecznych analizowana w tej dziedzinie nie istnieje w próżni. Jest to o tyle istotne, że inne obszary badań, zwłaszcza nauki społeczne, dostarczają wielu interesujących danych na ten temat, począwszy od samych definicji pojęć, którymi tutaj operujemy, a które w ujęciu przekładoznawczym traktowane są dość intuicyjnie. Henryk Król stwierdza, że kompetencje to pewne predyspozycje w zakresie wiedzy, umiejętności i postaw, które pozwalają na efektywną realizację zadań, zgodnie ze standardami określonymi dla zawodu [2006: 82]. Istnieje ogólna tendencja do dzielenia tychże kompetencji na dwie grupy [zob. Armstrong 2006; Boyatzis 1982]: 
- kompetencje twarde (zwane również umiejętnościami technicznymi) to kwalifikacje zawodowe, często potwierdzane certyfikatami i dyplomami, które pozwalają na skuteczne wypełnianie określonej roli w miejscu pracy. Często kojarzą się ze specjalistyczną wiedzą w dziedzinie zawodowej;

- kompetencje miękkie (nazywane również zdolnościami interpersonalnymi, społecznymi lub behawioralnymi) to pewne szczególne cechy społeczne, zdobyte podczas edukacji i osobistych doświadczeń, które mogą wpływać na jakość i efektywność pracy. Zazwyczaj odnoszą się do umiejętności pracy z innymi ludźmi.

Tendencja do dzielenia kompetencji na te dwie grupy jest dość dobrze ugruntowana w naukach społecznych i może być uznana za dobry kompromis między umiejętnościami technicznymi - sugerowanymi przez konkretne dziedziny nauki, takie jak właśnie przekładoznawstwo - oraz umiejętnościami interpersonalnymi, które interesują głównie badaczy ludzkiej natury w bardziej ogólnym sensie, czyli filozofów, psychologów, a nawet psychiatrów. Dla przykładu, jednym z pionierów badań nad tą kwestią był psycholog Edward Thorndike. Na początku lat 20. ubiegłego wieku badał i próbował zdefiniować zjawisko, które nazwał inteligencja społeczna. Z kolei w latach 30 . grupa psychiatrów analizowała to zjawisko z perspektywy braków w tym zakresie wśród osób z zaburzeniami psychicznymi [Spitzberg i Cupach 2012: 1]. I chociaż w obrębie wszystkich dyscyplin i badań pojawiało się wiele nazw dla określenia umiejętności społecznych, co sprawia, że interdyscyplinarne porównanie jest problematyczne ${ }^{1}$, istnieją pewne cechy, które mogą pomóc w stworzeniu ogólnej definicji.

Po pierwsze, w interakcji społecznej kompetencja zazwyczaj oznacza wiedzę, zdolności i zachowanie, które charakteryzują daną osobę, wrażenia, jakie wywołuje w innych i, ogólniej, jakość interakcji społecznych [ibidem: 6]. Jakość ta jest zwykle powiązana z dwiema cechami: efektywnością, którą można zazwyczaj zmierzyć poprzez pomyślne osiągnięcie celu lub realizacji zadania, oraz adekwatnością, która oznacza umiejętną adaptację do istniejących reguł zachowania [ibidem: 7]. Co więcej, kompetencje społeczne, choć trudne do zmierzenia, nie są pojęciem zero-jedynkowym, ale raczej rozwijają się w sposób stopniowy i można je posiąść w mniejszym lub większym stopniu [ibidem: 8]. Oznacza to, że

\footnotetext{
1 Bardziej wszechstronny przegląd można znaleźć w: Spitzberg i Cupach 2012: 2-4.
} 
dana umiejętność społeczna jest cechą osobistą, której posiadanie na satysfakcjonującym poziomie pozwoli na pomyślne osiągnięcie celu, zgodnie z przyjętą etykietą. Jeśli przyjmiemy taką definicję, to w kontekście przekładu pożądane kompetencje miękkie byłyby wszystkimi umiejętnościami społecznymi i interpersonalnymi, które pomagałyby tumaczowi w wykonaniu jego zadania.

Oczywiście bardzo trudno jest ustalić pełną listę takich kompetencji. Istnieje wiele propozycji, opracowanych $\mathrm{z}$ różnych perspektyw: począwszy od interakcji w codziennych kontaktach na płaszczyźnie osobistej, a skończywszy na bardzo specyficznych wymaganiach dla określonych zawodów (dla lekarzy, psychologów, nauczycieli itp.). Listy przygotowane na potrzeby biznesu, czyli dla skutecznego zarządzania zasobami ludzkimi lub - bardziej konkretnie - procesu rekrutacji, są być może najciekawsze, ponieważ tworzy się je w celu zaspokojenia ściśle określonej potrzeby, tj. wypełnienia luki, która może istnieć na rynku pracy. Mają one tendencję do koncentrowania się na zapotrzebowaniu na określoną umiejętność w danym zawodzie, a nie na wysoce teoretycznej i abstrakcyjnej wizji tego, jakie kompetencje dana osoba powinna posiadać w konkretnym zawodzie. Dla przykładu, w 2015 roku przeprowadzono badanie, które miało ustalić listę umiejętności społecznych, które powinien posiadać programista, aby móc awansować na stanowisko kierownika projektu [Werewka i Wietecha 2015]. Część tych badań polegała na analizie istniejących ofert pracy i określonych w nich wymagań. Autorzy, w toku analizy, zaproponowali listę umiejętności miękkich, podzielonych na cztery grupy: kompetencje osobiste (zob. tabela 1), kompetencje społeczne (zob. tabela 2), kompetencje kierownicze (zob. tabela 3) oraz kompetencje zawodowe, obejmujące głównie wiedzę z zakresu funkcjonowania danej firmy. Do tej listy autorzy dodają również bliżej niesprecyzowaną piątą grupę, nazwaną kompetencjami dziedzinowymi (branżowymi).

Te i podobne podejścia do kwestii kompetencji zdają się niezwykle interesujące i pomagają $\mathrm{w}$ lepszej systematyzacji określonych umiejętności w badanej dziedzinie, przepuszczając jednocześnie stawiane hipotezy przez bardzo „,praktyczny” filtr wymagań rynku. Interesujące zatem powinno być zastosowanie sugerowanych przez inne dyscypliny narzędzi do badań rynku tłumaczeniowego. 


\section{Kompetencje miękkie tlumacza na rynku pracy}

Propozycja Werewki i Wietechy jest bardzo interesująca, ponieważ została przygotowana w odpowiedzi na istniejące potrzeby rynku pracy i może stanowić dobry punkt wyjścia do proponowanej analizy. Interesowałoby nas zatem powtórzenie części proponowanego badania w kontekście rynku pracy tłumaczy i zaobserwowanie, jakie są kwalifikacje w dziedzinie kompetencji miękkich, których poszukują pracodawcy. I choć faktem pozostaje, że bardzo mały procent thumaczy zatrudnionych jest na etacie (jest to kwestia, która niewątpliwie wymaga dalszych badań²), to niemniej pojawiają się na rynku oferty pracy z funkcją „tłumacza” zawartą $\mathrm{w}$ takiej czy innej formie w opisie stanowiska. Nie jest ich zbyt dużo, dlatego materiał badawczy jest niestety ograniczony, a dodatkowo są one najczęściej związane z bardziej ogólnym zawodem asystenta lub pracownika biurowego połączonego z obowiązkami tłumacza, jednak mogą dostarczyć wystarczających danych, aby ustalić, jakie są umiejętności społeczne wymaganie w tej pracy.

Ze wszystkich grup zaproponowanych dla branży IT w naszej analizie wykorzystaliśmy pierwsze trzy, dochodząc do wniosku, że pozostałe propozycje, nawet jeśli dotyczą kompetencji miękkich, odnoszą się głównie do umiejętności, które rozwija się już w trakcie zatrudnienia w danej firmie, więc raczej nie pojawią się w ofertach. W maju 2018 roku przeanalizowano 60 ofert pracy pochodzących $\mathrm{z}$ międzynarodowych stron internetowych: monster.com, trovit.co.uk oraz jednej polskiej - pracuj. pl. Ogłoszenia zostały wybrane według jednego kryterium: musiały zawierać $\mathrm{w}$ opisach stanowiska tłumaczenie jako jedną z głównych czynności zawodowych, nawet jeśli nazwa tego stanowiska nie wskazywała na to jednoznacznie. Następnie oferty pracy zostały dokładnie przeanalizowane pod kątem występowania w podanych oczekiwaniach wobec potencjalnych pracowników cech, które uznać można za kompetencje miękkie. Gdy takie określenia wystąpiły, zostawały one następnie ,przetłumaczone" na ustaloną terminologię, aby uniknąc tworzenia kolejnych synonimów dla jednej i tej samej umiejętności. Co ciekawe, około 10\% ofert pracy nie zawierało żadnych wymagań dotyczących kompetencji

2 Interesujące pytanie stawia w swoim artykule Joanna Dybiec-Gajer, a mianowicie, gdzie kończy się kształcenie tłumacza, a zaczyna kształcenie przedsiębiorców. Podaje ona również, za Samuelssonem-Brownem, listę kompetencji, które należą bardziej do tej drugiej dziedziny [2012]. 
miękkich. Pozostałe ogłoszenia pozwoliły na stworzenie zarysu listy kompetencji społecznych, których oczekuje pracodawca.

Większość z kompetencji osobistych zaproponowanych przez Werewkę i Wietechę odnajdujemy, choć w różnym stopniu, w wymaganiach dla tłumaczy (tabela 1). Bez wątpienia najważniejszymi kompetencjami w tej grupie były sumienność i dokładność, które pojawiły się w ponad połowie ofert pracy. Na drugim miejscu znalazła się kreatywność - co czwarty pracodawca szukał tej cechy u tłumacza, a zaraz za nią znalazły się samodzielność, zaangażowanie i dążenie do rozwoju zawodowego. Interesujący jest fakt, że asertywność znalazła się na ostatnim miejscu tego zestawienia z tylko jednym ,trafieniem”.

Tabela 1

\begin{tabular}{|c|c|c|}
\hline & KOMPETENCJA MIĘKKA & LICZBA OGLOSZEŃ \\
\hline \multirow{11}{*}{ 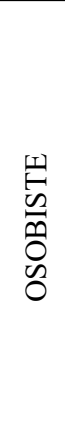 } & wytrwałość i konsekwencja & 2 \\
\hline & elastyczność & 6 \\
\hline & profesjonalizm i etyka & $6(0 \mathrm{w}$ polskich ogłoszeniach $)$ \\
\hline & kreatywność & 15 \\
\hline & sumienność i dokładność & 33 \\
\hline & myślenie analityczne & 7 \\
\hline & odporność na stres & 9 \\
\hline & asertywność & 1 \\
\hline & samodzielność & 14 \\
\hline & zaangażowanie & 12 \\
\hline & dążenie do rozwoju & 12 \\
\hline
\end{tabular}

Wśród kompetencji społecznych najważniejsza okazała się komunikatywność, która pojawiła się w niemal połowie ogłoszeń (tabela 2). Warto jednak dodać, że wyrażenia typu „komunikatywna znajomość języka” nie były brane pod uwagę, gdyż umiejętność ta należy do kompetencji twardych i nie opisuje cech, które nas interesowały. Znaczący wydaje się fakt, że budowanie relacji i pracę zespołową uznawano za dość ważne - wbrew powszechnej opinii, że thumacz pracuje zwykle sam. Żaden z przyszłych pracodawców nie oczekiwał, iż tłumacze będą się dzielić wiedzą i doświadczeniem. 
Tabela 2

\begin{tabular}{|c|c|c|}
\hline & KOMPETENCJA MIĘKKA & LICZBA OGŁOSZEŃ \\
\hline \multirow{6}{*}{ 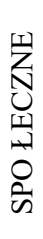 } & budowanie relacji & 19 \\
\hline & praca zespołowa & 13 \\
\hline & komunikatywność & 29 \\
\hline & orientacja na klienta & $5(0 \mathrm{w}$ polskich ogłoszeniach $)$ \\
\hline & dzielenie się wiedzą i doświadczeniem & 0 \\
\hline & kultura osobista & 4 \\
\hline
\end{tabular}

Analiza wyników wymagań w zakresie kompetencji kierowniczych (tabela 3) nie dostarcza wielu danych, poza tym, że tłumacze najwyraźniej nie są i nie mają być liderami. Jedynym znaczącym wynikiem, który pojawił się w ponad połowie ofert, była organizacja pracy, która dla celów tego opracowania była traktowana jako umiejętność zarządzania zadaniami jednej osoby, w odróżnieniu od planowania i koordynowania, które rozumieliśmy jako nadzór nad zespołem pracowników. Co do reszty wyników w tej grupie, to nie są one zaskakujące, jeśli rzeczywiście przyjmiemy, że tłumacz nie pełni funkcji kierowniczej, choć dość niski wynik takich kompetencji jak branie odpowiedzialności czy orientacja na cel wydaje się interesujący:

Tabela 3

\begin{tabular}{|c|c|c|}
\hline & KOMPETENCJA MIĘKKA & LICZBA OGŁOSZEŃ \\
\hline \multirow{4}{*}{} & planowanie i koordynacja & 0 \\
\cline { 2 - 3 } & szkolenie i uczenie & 0 \\
\cline { 2 - 3 } & mobilizowanie innych & 0 \\
\cline { 2 - 3 } & branie odpowiedzialności & 5 \\
\cline { 2 - 3 } & zarządzanie zespołem & 3 \\
\cline { 2 - 3 } & orientacja na cel & 34 \\
\cline { 2 - 3 } & organizacja pracy & 0 \\
\cline { 2 - 3 } & delegowanie & 0 \\
\cline { 2 - 3 } & nastawienie biznesowe & 0 \\
\hline
\end{tabular}

Podsumowując, najważniejszymi kompetencjami, które zostały wymienione w kwalifikacjach oczekiwanych przez pracodawców, były: organizacja pracy z 34 wzmiankami w ofertach, sumienność i dokładność z 33 wynikami oraz komunikatywność z 29. Dalej na liście znajdujemy: 
budowanie relacji z 19 trafieniami, kreatywność, która pojawiła się 15 razy, samodzielność (14) i praca zespołowa (13), zaangażowanie (entuzjazm, motywacja itp.) i dążenie do rozwoju - po 12 każde oraz odporność na stres (9). Kompetencje, które znalazły się w mniej niż 7 ogłoszeniach, to: myślenie analityczne, elastyczność, profesjonalizm i etyka, branie odpowiedzialności, orientacja na klienta, kultura osobista, orientacja na cel, wytrwałość i konsekwencja oraz asertywność, z jednym tylko trafieniem. Reszta umiejętności - tj. dzielenie się wiedzą i doświadczeniem, planowanie i koordynowanie (w odniesieniu do innych), szkolenie i uczenie, mobilizowanie innych, zarządzanie zespołem, delegowanie, nastawienie biznesowe i ogólnie pojęte przywództwo - nie była wymagana $\mathrm{w}$ żadnej z ofert pracy.

\section{Wnioski}

Nie ulega wątpliwości, że ilość dostępnego do analizy materiału nie pozwala na zaproponowanie pełnej listy kompetencji miękkich wymaganych na rynku pracy. Dopiero badania na szerszą skalę pozwoliłyby ustalić nie tylko kompletną listę pożądanych kompetencji, ale też znaczenie każdej z wymienionych cech. Ponadto przy tworzeniu takiego zestawienia należałoby wziąć pod uwagę fakt, że większość tłumaczy w rzeczywistości prowadzi własną działalność gospodarczą, a zatem konieczne byłoby uwzględnienie poglądu ich samych na temat kluczowych umiejętności i przeprowadzenie badań podobnych do tych zaproponowanych przez Albin [2012]. Jednak stworzenie kompletnej listy kompetencji miękkich nie było celem tego pilotażowego badania. Było nim wykazanie sporych rozbieżności między propozycjami przekładoznawców oraz standardami nauczania zaproponowanymi dla tej specjalności a realiami rynku pracy. Wszystko wskazuje na to, że nie ma bezpośredniego związku między teorią tłumaczenia a praktyką pośredników językowych - żadna z proponowanych list, a nawet grup kompetencji miękkich nie została potwierdzona przez analizę istniejących ofert pracy. Można wprawdzie argumentować, że potencjalni pracodawcy nie są najbardziej kompetentną grupą, aby decydować o tym, jakie cechy powinni mieć tłumacze, i prawdopodobnie jest $\mathrm{w}$ tym sporo racji. Niemniej jednak ich potrzeby zdecydowanie należy wziąć pod uwagę, chociażby ze względów czysto praktycznych praca tłumacza jest wszakże zawodem usługowym i nie da się w jej toku pominąć oczekiwań i potrzeb klienta. 
Podsumowując, daje się zauważyć pilną potrzebę dalszej analizy problemu i przedstawienia takiej propozycji listy kompetencji miękkich, która pogodziłaby wizje teoretyków, dydaktyków, potencjalnych pracodawców oraz, co nie mniej ważne, samych thumaczy. Listy, która budowałaby na osiągnięciach innych dziedzin naukowych i która ujednoliciłaby terminologię i definicje już stosowane w badaniach. A dodatkowo takiej, która ostatecznie potwierdziłaby znaczenie „czynnika ludzkiego” w procesie tłumaczenia. Do dziś, niestety, umiejętności społeczne są często pomijane $\mathrm{w}$ zestawieniach kompetencji, ponieważ ,ttumaczowi odmawia się prawa do odczuwania emocji (maszyny nie czują), popełniania błędów (maszyny ich nie popełniają) oraz bycia częścią społeczeństwa i wchodzenia w interakcje (maszyny są systemami zamkniętymi)" [Albin 2012: 36, tłum. K.K.J.]. Otworzenie się przekładoznawstwa na narzędzia wypracowane $\mathrm{w}$ innych dziedzin nauki, takie jak sugestia autorstwa Werewki i Wietechy przedstawiona $\mathrm{w}$ analizie, może być dobrym punktem wyjścia do takich badań.

\section{Bibliografia}

Albin, J. (2012), „Kompetencja z punktu widzenia thumacza”, [w:] Maria Piotrowska et al., red. Kompetencje thumacza, Krakowskie Towarzystwo Popularyzowania Wiedzy o Komunikacji Językowej „Tertium”, Kraków 31-48.

Albin, J. (2014), The Reflective Translator. Strategies and Affects of Self-directed Professionals, Peter Lang Editions, Frankfurt.

Armstrong, M. (2006), A Handbook of Human Resource Management Practice, Kogan Page Publishers, London-Philadelphia.

Bednarczyk, A. (2005), Wybory translatorskie. Modyfikacja tekstu literackiego w przektadzie i kontekst asocjacyjny, Oficyna Wydawnicza „Leksem”, Lask.

Bednarczyk, A. (2012), ,Jeszcze raz o dominancie. Piosenka autorska - dominanta meliczna", Między Oryginatem a Przektadem. 18: 39-57.

Biel, Ł. (2012), „Kompetencja w zakresie świadczenia usług thumaczeniowych a uczenie się przez projekt", [w:] Maria Piotrowska et al., red. Kompetencje thumacza, Krakowskie Towarzystwo Popularyzowania Wiedzy o Komunikacji Językowej „Tertium”, Kraków 97-105.

Bogusz-Przybylska, K. (2012), Modele kompetencji i definiowanie kompetencji w organizacjach, HR Wisdom Keeper, [online] https://hrwisdomkeeper.wordpress.com/2012/10/09/modele-kompetencji-i-definiowanie-kompetencji-worganizacjach/, 3.04.2018. 
Boyatzis, R. (1982), The Competent Manager: A Model for Effective Performance, John Wiley \& Sons, New York-Chichester-Brisbane-Toronto-Singapore.

Brożyna-Reczko, M. (2017), „Kompetencja twórcza thumacza. O potrzebie kształcenia kreatywnego myślenia i pisania", Między Oryginałem a Przekładem. 23 (38): 11-33, https://doi.org/10.12797/MOaP.23.2017.38.01.

Brzozowski, J. (2004), „Czy istnieje w Polsce szkoła hermeneutyczna w przekładzie?", Między Oryginałem a Przekładem. 9: 23-38.

Dybiec-Gajer, J. (2012), „Kompetencje profesjonalnego thumacza a kształcenie i sukces zawodowy. Model kompetencji EMT z perspektywy polskich thumaczy w Parlamencie Europejskim", [w:] Maria Piotrowska et al., red. Kompetencje tlumacza, Krakowskie Towarzystwo Popularyzowania Wiedzy o Komunikacji Językowej „Tertium”, Kraków 163-189.

EMT Competence Framework 2017, [online] https://ec.europa.eu/info/sites/info/ files/emt_competence_fwk_2017_en_web.pdf, 13.08.2018.

Etkind, E., Faigel, M. (1967), „Comparative Stylistics: a Guide to the Art of Translation", Sage Journals, https://doi.org/10.1177/039219216701505703.

Gentile, A., Ozolins, U., Vasilakakos, M. (1996), Liaison Interpreting: A Handbook, Melbourne University Press, Melbourne.

Gile, D. (1995), Basic Concepts and Models for Interpreter and Translator Training, John Benjamins Publishing Company, Amsterdam-Philadelphia, https://doi.org/10.1075/btl.8(1st).

Grosbart, Z. (2006), „O arcytrudnej sztuce przekładu”, Studia o Przekładzie. 21. Jakobson, R. (1959), „On Linguistic Aspects of Translation”, [w:] Reuben Arthur Brower, red. On Translation, Harvard University Press, Cambridge, MA 232-239.

Katan, D. (1999), Translating Cultures. An Introduction for Translators, Interpreters and Mediators, St. Jerome Publishing, Manchester.

Kelly, D. (2014), A Handbook for Translator Trainers: A Guide to Reflective Practice, Routledge, New York, https://doi.org/10.4324/9781315760292.

Król, H., Ludwiczyński, A. (red.) (2006), Zarządzanie zasobami ludzkimi, Wydawnictwo Naukowe PWN, Warszawa.

PACTE (2009), „Results of the Validation of the PACTE Translation Competence Model: Acceptability and Decision Making”, Across Languages and Cultures. 10(2): 207-230, https://doi.org/10.1556/Acr.10.2009.2.3.

Piotrowska, M. (2007), Proces decyzyjny thumacza: podstawy metodologii nauczania przektadu pisemnego, Wydawnictwo Naukowe Akademii Pedagogicznej, Kraków. 
Piotrowska, M. (2016), Proces decyzyjny thumacza. Zarys metodyki nauczania przektadu, Wydawnictwo C.H. Beck, Warszawa.

Płuska, K. (2017), „Miękko o kompetencjach”, [online] https://www.katarzynapluska.pl/kompetencje-miekkie-i-twarde-czym-sa/, 15.08.2018.

Pöchhacker, F. (2004), Introducing Interpreting Studies, Psychology Press, London, https://doi.org/10.4324/9780203504802.

Spitzberg, B., Cupach, W. (2012), Handbook of Interpersonal Competence Research, Springer Science \& Business Media, New York-BerlinHeidelberg-London-Paris-Tokyo.

Toury, G. (1995), Descriptive Translation Studies and Beyond, John Benjamins Publishing Company, Amsterdam-Philadelphia, https://doi.org/10.1075/ btl.4.

Vinay, J. P., Darbelnet, J. (1958), Stylistique comparée du français et de l'anglais, Didier, Paris.

Werewka, J., Wietecha, M. (2015), „Analiza wpływu kompetencji miękkich przy przejściu programistów na stanowiska kierowników projektów", Informatyka ekonomiczna/Business Informatics. 4(38): 64-90.

\section{STRESZCZENIE}

Artykuł podejmuje temat kompetencji miękkich, ukazując go z perspektywy przekładoznawstwa, by następnie zestawić go z badaniami poświęconymi temu zagadnieniu w innych dziedzinach naukowych. Analiza umiejętności społecznych wymaganych na rynku pracy, wykonana za pomocą narzędzi wypracowanych m.in. przez nauki społeczne, ukazuje rozbieżności pomiędzy kompetencjami tłumacza zaproponowanymi przez przekładoznawców a wynikami badań w pokrewnych dyscyplinach oraz tym, co o kwalifikacjach zawodowych myślą potencjalni pracodawcy.

Słowa kluczowe: kompetencje miękkie, umiejętności społeczne, kwalifikacje tłumacza

\section{SUMMARY}

\section{Soft Skills in Translation: An Interdisciplinary Approach}

The article reviews the topic of soft skills in Translation Studies, to compare it with the research regarding this issue in other disciplines. An analysis of the competences required by the work market with the tools 
"borrowed" from Social Sciences helps to demonstrate the discrepancies between the proposals of T.S. regarding translator's skills and the theories offered by other branches of knowledge, and, perhaps more importantly, the opinions about the desired qualifications professed by the potential employers.

Keywords: soft skills, social competences, translator's qualifications 